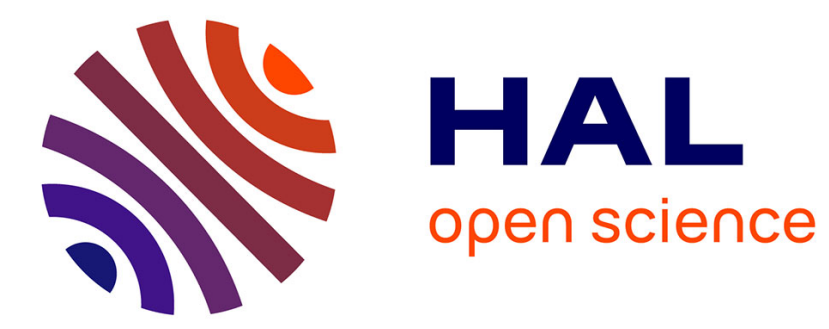

\title{
Culture or inequality in sex-selective abortion?
}

Miriam Ticktin

\section{To cite this version:}

Miriam Ticktin. Culture or inequality in sex-selective abortion?. Ethnicities, 2005, 5 (2), pp.266-271. 10.1177/146879680500500206 . hal-00571827

\section{HAL Id: hal-00571827 \\ https://hal.science/hal-00571827}

Submitted on 1 Mar 2011

HAL is a multi-disciplinary open access archive for the deposit and dissemination of scientific research documents, whether they are published or not. The documents may come from teaching and research institutions in France or abroad, or from public or private research centers.
L'archive ouverte pluridisciplinaire HAL, est destinée au dépôt et à la diffusion de documents scientifiques de niveau recherche, publiés ou non, émanant des établissements d'enseignement et de recherche français ou étrangers, des laboratoires publics ou privés. 
SAWITRI SAHARSO is a Senior Lecturer in the Department of Social Cultural Sciences of the Free University Amsterdam. Address: Department of Social Cultural Sciences, Free University, De Boelelaan 1081, 1081 HV Amsterdam, The Netherlands. [email:S.Saharso@fsw.vu.nl]

\section{Culture or inequality in sex-selective abortion?}

\section{A response to Sawitri Saharso}

\section{MIRIAM TICKTIN}

University of Michigan

Sawitri Saharso's article on sex-selective abortion amongst minority populations in the Netherlands comes at an important moment: immigration and the issue of integration of immigrant and minority populations occupy a central place in both public discourse and policy-making European-wide. Indeed, the issues of immigration and integration have played a significant role in election outcomes across Europe. Saharso goes to the heart of the matter in addressing the role of women and gender, which occupies a pivotal place in the debate over immigration. Not unlike the colonial era, when the perceived oppression of women in colonized regions was used as a benchmark of the barbarity of that culture in contrast to the modernity of the West, today, a similar process is occurring in the post-colonies. As Saharso points out, a concern with gender inequality often functions as a proxy for anti-immigrant and or anti-Muslim discourses and practices. She argues convincingly that feminism requires a contextual approach, one that allows no easy a priori moral positions. This approach leads her to suggest that access to abortion as well as pre-natal diagnostic techniques should be available equally to all women in the Netherlands, wherever they come from, and whatever they believe, and whether or not some choose to use it to abort female fetuses in favour of males. This call for equal access, she suggests, is largely because in the Netherlands, sex selective abortion has not been proven to be a common practice; hence women's right to autonomy trumps the risk of undermining sexual equality.

I generally agree with Saharso's conclusions, and, in particular, I agree with her suggestion to enhance immigrant women's ability to make choices by securing their residency status, and informing them of their rights, rather 
than by enforcing targeted legal bans against diagnostic techniques. Because her intervention is such an important one, and because she goes a long way in putting policy on the right track, I want to build on her conclusions to suggest that an approach that looks at more salient aspects of the context, questioning the role of inequality and domination and not simply looking at culture, would further illuminate the debate around sexselective abortion (SSA), while offering other possible solutions. What I see as an overemphasis on culture here derives from the framing of the argument: Saharso focuses on a discourse that posits feminism and multiculturalism as oppositional. Even though she ultimately and effectively demonstrates that this need not be the case, in laying these out as the parameters of the argument, she diverts attention from some of the more significant issues. Indeed, the framing often serves to replicate the same stereotypes that she works to undo. I will focus my comments on three issues.

First, I want to elaborate on how the feminism-multiculturalism opposition embedded in Saharso's argument works to elide structural issues that shape so-called cultural practices. Even while stating that immigrant/ minority women are not prisoners of their culture, for Saharso, culture still plays a central role in explaining SSA. She suggests that the roots of the problem (of SSA) 'lie in the patriarchal cultural traditions that make daughters the undesired sex.' Similarly, she claims that these women have a 'culturally inspired desire for SSA.' Indeed, Saharso sets up the problem as one of committing to 'multicultural respect,' without compromising gender injustice. Her contextual approach involves comparing the practice of SSA in the Netherlands to that in India, and demonstrating that the problem requires a different moral stance in the Netherlands, because of the small number of people practicing it. This allowance of SSA in the North stands in contrast to the prohibition against SSA in India which bans pre-natal diagnostic technology.

While Saharso argues convincingly that national context matters, what is not apparent is what, precisely, culture means, how it functions, why it can or should be compared across India and the Netherlands (the origin of those supposedly practicing SSA in the Netherlands is not mentioned), and what 'multicultural respect' involves. What is this culture that makes women commit SSA? Where are these patriarchal traditions from? The impression given is that they are static, fixed across geography and history, and the difference between India and the Netherlands is simply one of numbers. What is not clear is that other aspects of these women's contexts shape their cultural practices, and that cultural practices are always contested, changing, and often contradictory: minority women's practices are shaped as much by their class backgrounds, their immigration status, their minority status, whether they face discrimination and racism from the majority population, their literacy, and so on. They are also influenced by 
global inequalities and disparities of power. ${ }^{1}$ Focusing on a notion of culture and cultural respect as the main source of contention depoliticizes the question of why these women have become a focal point without significant evidence about SSA, ignoring the histories and legacies of colonialism and racism that now shape the imagery around Muslim and 'third-world' women. It also ignores the question of power and domination: what are the forces that help shape these women's lives - how do the global inequalities which lead to immigration shape their worlds, practices and choices? Indeed, it has been shown that the racism faced by minorities has often worked to engender practices that distinguish minority from majority, precisely as a form of agency and resistance. ${ }^{2}$ Similarly, the rates of violence against women in immigrant communities have been shown to be correlated with powerlessness, racism and economic hardship: here, what immigrant communities hold in common is their structural position, not their supposedly violent or patriarchal cultures. ${ }^{3}$ Why is the line of moral questioning about SSA not focused on state violence, discrimination and disenfranchisement, forces that shape and often define cultural practices? ${ }^{4}$ If the issue of SSA is to be addressed, both morally and politically, it is necessary to broaden the contextual approach to examine not only the context in which culture happens, but what makes up cultural practices themselves. Indeed, we must examine the specific nature of patriarchies, as embedded in economic and geopolitical relationships.

Second, I will address the concept of moral autonomy as used in the article. Saharso asks whether non-western women make the choice 'freely' to have an SSA, i.e. whether non-western women have moral agency and autonomy. She suggests that non-western women's ability to make decisions autonomously is likely hampered by their families and family pressure; for this, women should be made aware of their rights to enhance autonomy 'against family pressure.' Thus she states that they are 'not necessarily morally inferior,' just without moral autonomy. I agree that it is critical to understand that immigrant women are often isolated and without access to the larger society, making them more vulnerable to many types of pressure - without resources, everyone's choices are limited. I would like to reframe the issue, however, to move it away from the implied notion that some women can live their lives outside of communities or families, indeed, that they can be autonomous individuals, apart from the particular and local, apart from the cultural and social. I am not interested in getting rid of moral judgment, nor the concepts of agency or freedom - I follow Wendy Brown when she says that despite the many challenges to the notion of the 'sovereign subject,' freedom remains a compelling concept, because it 'still marks the ground between lives which are relatively controlled by those who live them and those that are less so' (Brown, 1995: 5). However, I do join those who argue that we are all embedded in larger social, political and cultural networks - that we 
are constituted by and through them - and thus I suggest that the moral autonomy Saharso is in search of here would be more useful if differently conceived. Positing the possibility of an individual outside the collective codes that we are all subject to threatens to re-inscribe the colonially derived notion that non-western women are more subject to their cultures than are western women, who are free. Culture is made visible as the constraining force for immigrant women, while erasing its role in Dutch women's lives: thus, for instance, when Dutch women have abortions, it is depicted as a choice made freely, based only on necessity - economic or medical. Culture goes unnamed, yet do cultural practices not shape what is understood as enough money to have a child, what a child needs to be healthy, and what, ultimately, constitutes the 'critical situation,' which by Dutch law legitimizes abortion? ${ }^{5}$ This notion of autonomy forecloses the idea that culture or other types of embeddedness can actually lead to agency or empowerment - what is at stake is power, not culture. Conceiving of people not only as socially embedded, but socially constituted opens new avenues by which to address the question of SSA: might women have more resources, and be freer or better able to control their lives by turning to different communities, or different kinship structures, rather than trying to stand tall as abstract, rights-bearing individuals? Indeed, the question then becomes in what does agency actually consist? Only once we know this can we work to enhance it. ${ }^{6}$

Taking an approach that acknowledges power, conflict and inequality is essential to understand not only the practice of SSA, but the debate around it, and what the stakes are in talking about or condemning it. Such an approach would acknowledge that multiculturalism as both a policy and discourse often obscures inequalities, putting culture in their stead. It would also help to explain what Saharso construes as a contradiction between the claim to self-determination and the claim to respect for the universal principle of sexual equality made by the joint national organizations of and for black, migrant and refugee women and the Women's Council on Development Aid, and what Saharso claims is their failure to see it as such. ${ }^{7}$ A different approach that moves beyond culture would show that these two are not, in fact, in conflict: rather, we are all embedded and certain conditions make it easier for us to make our own choices (i.e. to be selfdetermining). With the right conditions - with resources - both women and men might indeed make different choices. The argument is that selfdetermination and sexual equality both can and would co-exist under conditions that allow for substantive choices.

Third, as a counterpoint to this debate on SSA, which, as Saharso rightly states, re-inscribes the opposition between culture-tradition-oppression, and modernity-rationality-liberalization, it helps to acknowledge that the women choosing SSAs are in fact in many ways quintessential modern liberal subjects. They are using new technologies and scientific advances to 
make choices and decisions about their bodies and their lives, and to act on them. While one may not agree with the practice of SSA, understanding these women as quintessentially modern suggests a different way to frame both the debate and the line of moral questioning.

\section{Notes}

1 See Volpp (2001) for an excellent description of the relationship between feminism and multiculturalism. To show how one must understand geopolitics to understand cultural and religious practices that are oppressive to women, she gives examples such as (a) sati, which was cultivated as a religious practice in collaboration with British colonialism, and (b) how the intensification of religious fundamentalism under the Taliban in Afghanistan, including the adoption of Hudood ordinances, relates to and was propped up by the USA's economic interests.

2 See Bhattacharjee (1992); Prashad (2000); Volpp (2001).

3 See Jiwani and Buhagiar (1997); Agnew (1998); Razack (2001).

4 A similar example can be found in the practice of excision (or FGM) amongst immigrant populations in France. Lionnet (1992) and Winter (1994) both demonstrate how the relationship of immigrants to the French state shapes the practice, with both the state and immigrant communities fighting for the power to discipline and control women's bodies as a way to define the interests of immigrant communities.

5 As Saharso states, abortion is only permitted under Dutch law if there is risk to the mother's life or health, or if the woman is in a critical situation which cannot be resolved in any other way - this critical situation includes psycho-social distress.

6 See Saba Mahmood (2001) for an exploration of the notion of agency amongst women who are part of the Islamic revival movement in Egypt. Mahmood suggests that the concept of agency used in much western feminist scholarship is limited in its ability to understand the lives of women whose desire, affect and will have been shaped by non-liberal traditions.

7 In an open letter (Vrouwenberaad Ontwikkelingssamenwerking, AISA, TARGUIA and TIYE International, 1997), they argue against the 'misplaced cultural relativism' which resulted in the acceptance of the practice of SSA by the Dutch minister of health.

\section{References}

Agnew, V. (1998) In Search of a Safe Place: Abused Women and Culturally Sensitive Services. Toronto: University of Toronto Press.

Bhattacharjee, A. (1992) 'The Habit of Ex-Nomination: Nation, Woman, and The Indian Immigrant Bourgeoisie' Public Culture 5(1): 19-44.

Brown, Wendy (1995) States of Injury: Power and Freedom in Late Modernity. Princeton, NJ: Princeton University Press.

Jiwani, Y. and Buhagiar, L. (1997) Policing Violence Against Women in Relationships: An Examination of Police Response to Violence Against Women in British 
Columbia. Vancouver, BC: Feminist Research, Education, Development \& Action Centre.

Lionnet, F. (1992) 'Feminisms and Universalisms: Universal Rights and The Legal

Debate Around the Practice of Female Excision in France', Inscriptions 6 ('Orientalisms and Cultural Differences' special issue edited by Mahmut Mutman and Meyda Yegenoglu).

Mahmood, S. (2001) 'Feminist Theory, Embodiment, and the Docile Agent: Some Reflections on the Egyptian Islamic Revival', Cultural Anthropology 16(2): 202-36.

Prashad, V. (2000) The Karma of Brown Folk. Minneapolis, MN: University of Minnesota Press.

Razack, S. (2001) 'A Violent Culture or Culturalized Violence? Feminist Narratives of Sexual Violence Against South Asian Women', Studies in Practical Philosophy 3(1): 80-104.

Vrouwenberaad Ontwikkelingssamenwerking (Women's Council on Development Aid), AISA, TARGUIA and TIYE International (1997) Open Brief aan Minister Borst (Open Letter to Minister Borst). Oegstgeest, 20 January.

Volpp, L. (2001) 'Feminism versus Multiculturalism', Columbia Law Review 101(5): 1181-218.

Winter, B. (1994) 'Women, the Law, and Cultural Relativism in France: The Case of Excision', Signs Summer: 939-74.

MIRIAM TICKTIN is Assistant Professor in Anthropology and Women's Studies at the University of Michigan. Address: Program in Women's Studies and Department of Anthropology, University of Michigan, 2114 Lane Hall, Ann Arbor, MI 48109, USA. [email: mticktin@umich.edu]

\section{'Between norms and practicalities'}

\section{A response to Sawitri Saharso}

\section{ANNE PHILLIPS}

\section{London School of Economics}

In her article 'Sex-selective abortion: Gender, culture and Dutch public policy', Sawitri Saharso makes two very important theoretical arguments, and employs them to address a specific policy issue that has arisen in the Netherlands. I find the general arguments compelling, and agree with her (no change) policy recommendation. I remain unclear, however, as to the wider implications regarding the relationship between normative and pragmatic arguments; and my comments are largely designed to tease these out. 